\title{
PENGARUH KONSENTRASI PENYALUT TERHADAP VIABILITAS BAKTERI DAN DAYA LARUT TABLET EFFERVESCENTPROBIOTIK
}

\section{The Effect of Filler Concentration on Bacteria Viability and Solubility Rate of Probiotic Effervescent Tablets}

\author{
Devi Ambarwaty Oktavia ${ }^{1 *}$, Feliatra ${ }^{2}$, dan Lora Lestari Lubis ${ }^{2}$ \\ ${ }^{1}$ Balai Besar Riset Pengolahan Produk dan Bioteknologi Kelautan dan Perikanan, Badan Riset dan Sumber Daya Manusia \\ Kelautan dan Perikanan, JI. KS.Tubun Petamburan VI, Slipi, Jakarta, Indonesia \\ ${ }^{2}$ Fakultas Perikanan dan IImu Kelautan, Universitas Riau, JI. HR Subantas KM 12.5, Kota Pekanbaru, Riau, Indonesia \\ *Korespondensi Penulis: devi_oktav@yahoo.co.uk
}

Diterima: 21 November 2017; Direvisi: 26 Februari 2018; Disetujui: 14 September 2018

\begin{abstract}
ABSTRAK
Upaya meningkatkan produksi udang dapat dilakukan melalui penggunaan probiotik. Untuk menjaga viabilitas bakteri probiotik, diperlukan usaha untuk melindungi bakteri dengan penyalut misalnya maltodekstrin. Perlindungan lebih lanjut dapat ditingkatkan dengan cara mengemas probiotik tersebut dalam tablet effervescent. Penelitian ini bertujuan untuk menguji viabilitas (jumlah bakteri) dan waktu larut probiotik yang sudah dicetak menjadi tablet effervescent dengan variasi konsentrasi penyalut. Metode penelitian yang digunakan adalah metode eksperimen; yaitu sampel air tambak udang diberi perlakuan 4 (empat) formula tablet effervescent (Formula I, II, III, IV) dengan 3 (tiga) konsentrasi penyalut yaitu 20\%, 30\% dan 40\% maltodekstrin. Masingmasing perlakuan dilakukan pengulangan sebanyak 2 kali. Pengujian Total Plate Count (TPC) dan waktu larut dilakukan untuk mengetahui konsentrasi penyalut tablet effervescent yang paling efektif. Formula tablet effervescent yang paling efektif dalam menjaga kestabilan bakteri adalah formula IV dengan konsentrasi maltodekstrin sebanyak 30\%. Formula ini menghasilkan tablet effervescent dengan jumlah bakteri sebanyak 6,46 log CFU/mL dan larut dalam waktu 20 menit.
\end{abstract}

KATA KUNCI: probiotik, tablet effervescent, Total Plate Count, viabilitas sel

\begin{abstract}
The efforts to increase shrimp production can be done through the use of probiotics. To maintain the viability of probiotic bacteria, it is necessary to protect bacteria with coating agent; such as maltodextrin. Such protection can be further enhanced by packing the probiotics in effervescent tablets. This study aimed to test the cell viability (the number of bacteria) and dissolved time of probiotics that have been modified into effervescent tablets with various filler concentrations. The research method used was an experimental method; in which the samples of shrimp pond water were added with a treatment of 4 (four) effervescent tablet formulas (Formula I, II, III, IV) with 3 (three) filler concentrations of $20 \%, 30 \%$, and $40 \%$ maltodextrin. Each treatment was repeated twice. Total Plate Count (TPC) and dissolution time analysis were carried out to determine the most effective concentration of effervescent tablet filler. The most effective effervescent tablet formula for maintaining bacterial stability was formula IV with a concentration of maltodextrin as much as $30 \%$. This formula formed the effervescent tablets with total bacteria of $6.46 \log \mathrm{CFU} / \mathrm{mL}$ and dissolution in 20 minutes.
\end{abstract}

KEYWORDS: probiotics, effervescent tablets, Total Plate Count, cell viability

\section{PENDAHULUAN}

Seiring dengan berkembangnya budidaya intensif udang di masyarakat, beberapa permasalahan muncul, baik pada sektor pembenihan maupun pembesaran. Beberapa kendala yang dihadapi antara lain adalah serangan penyakit, pertumbuhan udang yang lambat, dan menurunnya kualitas lingkungan budidaya. Masalah penyakit yang umum terdapat pada budidaya udang antara lain vibriosis yang disebabkan oleh bakteri Vibrio harveyi (Kanjana, Tawut, Asuvapongpatana, Withyachumnarnkul \& Wongprasert, 2011) dan penyakit bercak putih yang disebabkan oleh WSSV (White Spot Syndrome Virus) 
yang dapat menyebabkan kematian hingga 100\% (Flegel, 2012). Sumber bakteri Vibrio spp. pada tambak dapat berasal dari air laut, benur yang digunakan, ataupun sedimen tambak itu sendiri (Atmomarsono, Muliani \& Tampangallo, 2010). Pencegahan dan penanggulangan penyakit pada udang windu dengan menggunakan obat-obatan dan antibiotik telah banyak dilakukan baik di dalam dan luar negeri (Karunasagar, Pai, Malathi, \& Karunasagar, 1994, Chanratchakool \& Limsuwan, 1998). Metode ini cukup efektif namun tidak dianjurkan karena adanya bahaya residu obat-obatan dan antibiotik pada organisme budidaya. Menurut Verschuere, Rombaut, Sorgeloos, dan Verstraete (2000) salah satu alternatif yang efektif untuk menghambat pertumbuhan bakteri patogen yaitu menggunakan bakteri probiotik sebagai musuh alaminya yang berperan sebagai kontrol biologis.

Aplikasi probiotik sebagai penambahan mikroba hidup pada lingkungan memiliki pengaruh yang menguntungkan bagi inang melalui modifikasi bentuk asosiasi dengan inang atau komunitas mikroba lingkungan hidupnya dan meningkatkan kualitas air (Farzanfar, 2006). Budidaya udang windu dan vaname secara intensif memerlukan bakteri probiotik untuk mempertahankan kualitas air agar tetap bagus. Menurut Poernomo (2004), alasan penggunaan probiotik salah satunya adalah membersihkan dasar tambak dari timbunan kotoran udang, sisa pakan, bangkai udang, klekap dan plankton. Menurut Muliani, Nurbaya dan Atmomarsono (2010), penggunaan bakteri probiotik sebagai pengurai bahan organik juga memberikan kontribusi terhadap perbaikan lingkungan budidaya yang berefek pada peningkatan kesehatan udang sehingga tidak mudah stres dan tahan terhadap serangan penyakit.

Variasi produk probiotik di pasaran seringkali menimbulkan masalah tersendiri karena pembudidaya kurang memahami dengan jelas cara penggunaannya. Komposisi jenis, waktu aplikasi, serta dosis yang tepat seringkali tidak dicantumkan dengan jelas sehingga pembudidaya menggunakannya secara tidak tepat (Najib, komunikasi pribadi, 2015). Salah satu langkah yang dapat dilakukan untuk melindungi bakteri probiotik ini adalah dengan enkapsulasi/penyalutan yang mampu melindungi bakteri probiotik secara efektif dari tekanan kondisi lingkungan (Susantho, 2012), salah satunya dengan menggunakan penyalut maltodekstrin. Osmond, Purwijantiningsih, dan Pranata (2015) meneliti bahwa enkapsulan maltodekstrin memiliki viabilitas lebih tinggi dibandingkan susu skim. Setelah dienkapsulasi dari probiotik cair menjadi serbuk probiotik, serbuk ini sangat sensitif terhadap suhu dan kelembaban
(Anekella, 2011; Chavarri, Maranon \& Villaran, 2015; Kailasapathy, 2002) sehingga perlu dijadikan tablet effervescent agar lebih intensif dalam melindungi bakteri probiotik (Nagashima, Pansiera, Baracat \& Gomez, 2013). Probiotik cair dienkapsulasi menjadi serbuk kemudian dimodifikasi dalam bentuk sediaan tablet effervescent. Modifikasi ini agar lebih praktis, efisien dalam penggunaannya dan sediaan probiotik yang dihasilkan dapat memberikan nilai-nilai spesifikasi yang stabil (Nagashima et al., 2013; Nisha, Milind \& Imran, 2013).

Telah banyak diketahui bahwa probiotik sangat berguna untuk hewan akan tetapi sediaan untuk pakan ternak yang mengandung probiotik terutama dalam bentuk bubuk tidak mudah. Untuk memastikan jumlah probiotik yang dibutuhkan dapat mencapai target, beberapa faktor harus diuji terlebih dahulu untuk meningkatkan stabilitas atau kelangsungan hidup produk probiotik. Agen enkapsulasi adalah formulasi tunggal atau kombinasi material yang dapat menahan kondisi sel yang stabil, berpotensi meningkatkan viabilitas dan stabilitas produksi, baik penyimpanan dan penanganannya serta melindungi sel di sepanjang prosesnya. Beberapa metode enkapsulasi probiotik telah dilaporkan oleh Kailasapathy (2002) adalah imobilisasi (penjeratan), enkapsulasi dan mikroenkapsulasi (spray drying, ekstrusi, emulsi dan pemisahan fase). Masalah yang sering terjadi pada pembuatan tablet effervescent adalah tablet yang dihasilkan terkadang bersifat rapuh sehingga mudah hancur atau terlalu mampat yang menyebabkan sukar larut. Fenomena tersebut disebabkan oleh penentuan formula dan penggunaan gaya tekan yang tidak optimum. Tablet effervescentyang rapuh mungkin saja larut, akan tetapi tidak tahan terhadap gangguan mekanis pada saat pendistribusian atau penyimpanan (Anon., 2004 dalam Ansar, Rahardjo, Noor \& Suyitno, 2006). Untuk memperoleh jumlah bakteri probiotik yang stabil maka perlu dilakukan penelitian tentang variasi konsentrasi penyalut pada viabilitas bakteri tablet effervescent probiotik asal Balai Penelitian dan Pengembangan Budidaya Air Payau (BPPBAP) Maros, Sulawesi Selatan.

\section{BAHAN DAN METODE}

\section{Bahan}

Bahan yang digunakan adalah probiotik cair RICA 1 yang berisi bakteri Brevibacillus sp. yang telah dikembangkan oleh Balai Penelitian dan Pengembangan Budidaya Air Payau (BPPBAP) Maros, Sulawesi Selatan (Tampangallo, Pakidi, \& Rantetondok, 2013). Probiotik cair ini dikeringkan 
menggunakan teknik spray drying (Teixeira, Castro \& Kirby, 1995a yang telah dimodifikasi) berkapasitas 5 $\mathrm{kg}$ per jam (sistem kontinyu) dengan suhu inlet $162 \pm 2{ }^{\circ} \mathrm{C}$ dan suhu outlet $80 \pm 2{ }^{\circ} \mathrm{C}$. Kontak dengan suhu inlet selama 2-3 detik. Laju alir umpan sebesar $20 \mathrm{~mL} /$ menit. Proses pengeringan probiotik cair ini dilakukan di CV. Mitra Niaga Indonesia, Leuwikopo, Bogor. Bahan-bahan untuk membentuk tablet effervescent yaitu asam sitrat, natrium bikarbonat, magnesium stearat dan laktosa dengan grade teknis. Bahan yang diperlukan untuk melakukan uji viabilitas bakteri adalah Triptone Soya Agar (TSA, Oxoid), $\mathrm{NaCl}$ $0,9 \%$.

\section{Metode}

Metode penelitian yang digunakan adalah metode eksperimen. Analisis data menggunakan Rancangan Acak Lengkap (RAL) faktorial dengan 2 faktor yaitu konsentrasi penyalut maltodekstrin $(20 \%, 30 \%$, dan $40 \%$ ) dan formula tablet effervescent (formula I, II, III, IV). Komposisi formula tablet dapat dilihat pada Tabel 1. Masing-masing perlakuan dilakukan pengulangan sebanyak 2 kali sehingga jumlah sampel menjadi 24 (Tabel 2). Uji yang dilakukan meliputi viabilitas sel bakteri dengan metode Total Plate Count (TPC), uji $\mathrm{pH}$ dan waktu larut tablet effervescent probiotik.
Pengolahan data dilakukan dengan menggunakan analisis ragam, uji lanjut menggunakan DMRT (Duncan's Multiple Range Test) dengan selang kepercayaan $5 \%$.

\section{Pembuatan tablet effervescent probiotik dengan metode granulasi basah}

Granul asam dan basa dibuat secara terpisah. Granul asam dibuat dengan campuran asam sitrat, laktosa dan alkohol $70 \%$ sebagai pengikat, sedangkan granul basa dibuat dengan campuran natrium bikarbonat, laktosa dan alkohol 70\% sebagai pengikat (Lestari dan Trisusilawati, 2010) terlihat pada Gambar 1.

Formulasi bahan dilakukan dengan memvariasikan persentase asam sitrat dan natrium bikarbonat dengan rasio berat (1:1, 1:2, 1:3 dan 1:4) yang telah dimodifikasi dari penelitian Ansar, Rahardjo, Noor dan Rochmadi (2009). Natrium bikarbonat sebagai sumber karbonat sedangkan asam sitrat sebagai sumber asam dan penambah kelarutan (Faradiba, Hasyim \& Zahriati, 2013).

Bahan-bahan yang digunakan terlebih dahulu dicampur hingga homogen pada ruangan berkelembaban $40 \%$. Proses pencampuran menggunakan granulasi basah yaitu memisahkan antara bahan yang asam yaitu asam sitrat dan granulasi basa yaitu Na bikarbonat.

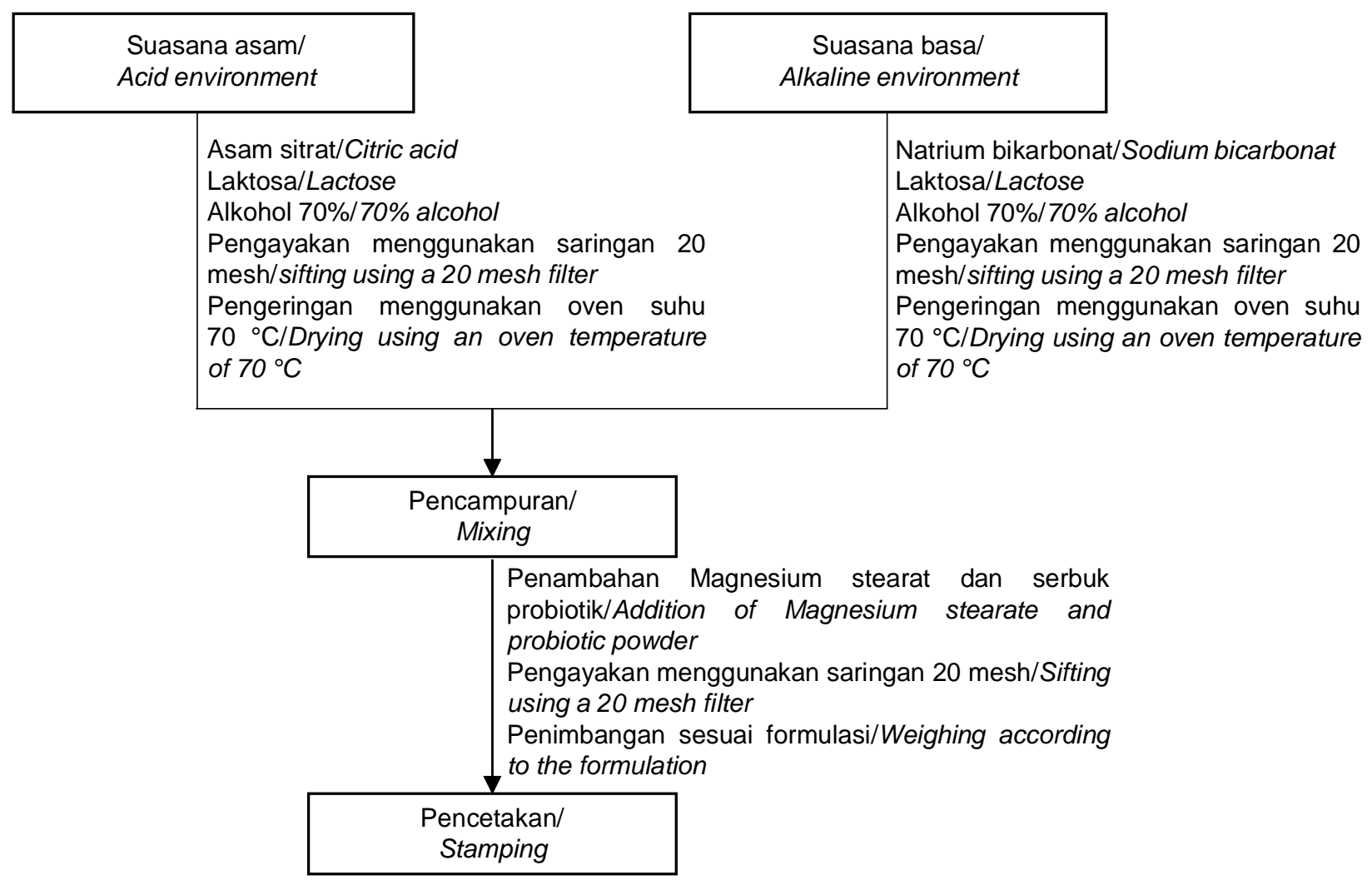

Gambar 1. Diagram alir pembuatan tablet effervescent probiotik

Figure 1. Flow chart of the process in producing the probiotic effervescent tablet 
Tabel 1. Formula tablet effervescent yang telah dimodifikasi dari Ansar et al. (2009) dan Anwar, Joshita dan Bahtiar (2010)

Table 1. Modified effervescent tablet formula from Ansar et al. (2009) and Anwar, Joshita and Bahtiar (2010)

\begin{tabular}{lcccc}
\hline \multirow{2}{*}{ Bahan $(\mathbf{m g}) /$ Ingredients $(\mathbf{m g})$} & \multicolumn{4}{c}{ Formula/Formula } \\
\cline { 2 - 5 } & I & II & III & IV \\
\hline Serbuk probiotik/Probiotics powder & 300 & 300 & 300 & 300 \\
Asam sitrat/Citric acid & 150 & 100 & 100 & 80 \\
Natrium bikarbonat/Sodium bicarbonate & 150 & 200 & 300 & 320 \\
Magnesium stearat/Magnesium stearate & 90 & 90 & 10 & 10 \\
Laktosa/Lactose & 110 & 110 & 90 & 90 \\
\hline Total/Total & 800 & 800 & 800 & 800 \\
\hline
\end{tabular}

Pencetakan tablet dilakukan dengan metode kompresi (Mohrle, Attwood, \& Banker, 1989). Bahan yang telah tercampur pada formula I sampai IV dimasukan ke dalam cetakan selanjutnya dimampatkan dengan gaya pengepresan. Pencetakan tablet dilakukan dengan menggunakan mesin penekan tablet mini.

Modifikasi yang dilakukan adalah persentase asam sitrat sebanyak $15 \%$ dan rasio asam sitrat dengan natrium bikarbonat adalah 1:1, 1:2, 1:3 dan 1:4.

\section{Uji waktu larut tablet effervescent}

Pada uji ini diambil 4 tablet dengan berat $800 \mathrm{mg}$ (formula I, II, III, IV) dari masing masing konsentrasi enkapsulan/penyalut yaitu 20\%, 30\% dan 40\%. Setiap tablet diuji satu per satu dalam beaker glass volume $200 \mathrm{~mL}$ berisi air tambak. Penghitungan waktu larut dimulai dari tablet dimasukkan hingga tablet habis larut (Dirjen POM, 1979 dan Anwar et al., 2010).

\section{Pengukuran $\mathrm{pH}$}

Uji pH larutan effervescent dilakukan dengan melarutkan satu tablet effervescent dalam $200 \mathrm{~mL}$ air tambak udang kemudian $\mathrm{pH}$ diukur dengan menggunakan kertas $\mathrm{pH}$ (Kailaku, Sumangat \& Hernani, 2012). Hasil pengukuran dikatakan baik apabila mendekati netral.

\section{Uji viabilitas bakteri probiotik}

Jumlah bakteri dihitung menggunakan metode TPC (Aneja, 2003 yang telah dimodifikasi). Sebanyak $1 \mathrm{~g}$ tablet effervescent $(800 \mathrm{mg})$ dihancurkan dan diencerkan secara bertingkat dalam $10 \mathrm{~mL}$ air tambak dan dihomogenkan dengan vorteks. Sampel

Tabel 2. Rancangan penelitian

Table 2. Research designs

\begin{tabular}{lcccccccc}
\hline Perlakuan/Treatments & & q1 & \multicolumn{2}{c}{ q2 } & \multicolumn{2}{c}{ q3 } & \multicolumn{2}{c}{ q4 } \\
\hline & $\mathrm{r} 1$ & $\mathrm{r} 2$ & $\mathrm{r} 1$ & $\mathrm{r} 2$ & $\mathrm{r} 1$ & $\mathrm{r} 2$ & $\mathrm{r} 1$ & $\mathrm{r} 2$ \\
$\mathrm{p} 1$ & $\mathrm{p} 1 \mathrm{q} 1 \mathrm{r} 1$ & $\mathrm{p} 1 \mathrm{q} 1 \mathrm{r} 2$ & $\mathrm{p} 1 \mathrm{q} 2 \mathrm{r} 1$ & $\mathrm{p} 1 \mathrm{q} 2 \mathrm{r} 2$ & $\mathrm{p} 1 \mathrm{q} 3 \mathrm{r} 1$ & $\mathrm{p} 1 \mathrm{q} 3 \mathrm{r} 2$ & $\mathrm{p} 1 \mathrm{q} 4 \mathrm{r} 1$ & $\mathrm{p} 1 \mathrm{q} 4 \mathrm{r2}$ \\
$\mathrm{p} 2$ & $\mathrm{p} 2 \mathrm{q} 1 \mathrm{r} 1$ & $\mathrm{p} 2 \mathrm{q} 1 \mathrm{r} 2$ & $\mathrm{p} 2 \mathrm{q} 2 \mathrm{r} 1$ & $\mathrm{p} 2 \mathrm{q} 2 \mathrm{r} 2$ & $\mathrm{p} 2 \mathrm{q} 3 \mathrm{r} 1$ & $\mathrm{p} 2 \mathrm{q} 3 \mathrm{r} 2$ & $\mathrm{p} 2 \mathrm{q} 4 \mathrm{r} 1$ & $\mathrm{p} 2 \mathrm{q} 4 \mathrm{r2}$ \\
$\mathrm{p} 3$ & $\mathrm{p} 3 \mathrm{q} 1 \mathrm{r} 1$ & $\mathrm{p} 3 \mathrm{q} 2 \mathrm{r} 2$ & $\mathrm{p} 3 \mathrm{q} 2 \mathrm{r} 1$ & $\mathrm{p} 3 \mathrm{q} 2 \mathrm{r} 2$ & $\mathrm{p} 3 \mathrm{q} 3 \mathrm{r} 1$ & $\mathrm{p} 3 \mathrm{q} 3 \mathrm{r} 2$ & $\mathrm{p} 3 \mathrm{q} 4 \mathrm{r} 1$ & $\mathrm{p} 3 \mathrm{q} 4 \mathrm{r2}$ \\
\hline
\end{tabular}

Keterangan/Annotation :

$r$ : ulangan/repeattion

q1 : Formula I/ Formula I

q2 : Formula II/ Formula II

q3 : Formula III/ Formula III

q4 : Formula IV/ Formula IV

p1 : konsentrasi $20 \%$ maltodekstrin/concentration of $20 \%$ maltodextrin

p2 : konsentrasi $30 \%$ maltodekstrin/concentration of $30 \%$ maltodextrin

p3 : konsentrasi $40 \%$ maltodekstrin/concentration of $40 \%$ maltodextrin 
disuspensikan dalam $\mathrm{NaCl} 0,9 \%$ dan dibuat serial pengenceran. Pengujian viabilitas sel probiotik dalam tablet effervescent dilakukan pada media TSA dengan metode sebar (spread) pada beberapa seri pengenceran. Sebanyak $1 \mathrm{~mL}$ larutan tablet effervescent diambil dan diencerkan dengan pengenceran $10^{-3}, 10^{-4}, 10^{-5}$. Sebanyak $0,1 \mathrm{ml}$ hasil pengenceran ditanam ke dalam cawan petri disposable berisi media TSA agar yang sudah beku kemudian diratakan dengan menggunakan spreader dan selanjutnya diinkubasi pada inkubator bersuhu $37^{\circ} \mathrm{C}$ selama 48 jam (Triana, Yulianto \& Nurhidayat, 2006 yang telah dimodifikasi). Pembacaan viabilitas serta penghitungan jumlah koloni menggunakan colony counter SCAN12000. Penghitungan jumlah koloni dilakukan sebanyak dua kali ulangan. Sebagai pembanding uji viabilitas bakteri probiotik menggunakan metode TPC juga dilakukan untuk probiotik cair dan probiotik serbuk

\section{HASIL DAN PEMBAHASAN}

\section{Penyalutan Bakteri Probiotik}

Bakteri probiotik cair RICA 1 (Brevibacillus sp.) yang digunakan dalam penelitian ini berasal dari BPPBAP (Balai Penelitian dan Pengembangan Budidaya Air Payau) Maros, Sulawesi Selatan. Dalam penelitian ini terdapat 3 konsentrasi penyalut (Faktor P) yaitu 20\%, 30\%, dan $40 \%$ maltodekstrin yang dicetak menjadi 4 formula tablet effervescent (Faktor
Q) dengan rasio asam sitrat dan natrium bikarbonat yang berbeda. Hasil pengujian TPC tablet effervescent pada konsentrasi penyalut $20 \%, 30 \%$ dan $40 \%$ maltodekstrin terlihat pada Gambar 2-4.

Pada Gambar 2 dan 3 dapat dilihat bahwa penurunan jumlah bakteri probiotik cair menjadi probiotik serbuk tidak signifikan baik menggunakan penyalut berkonsentrasi $20 \%$ maupun $30 \%$ maltodekstrin, sedangkan pada penyalut konsentrasi $40 \%$ terjadi penurunan secara nyata pada probiotik serbuk (Gambar 4). Pada konsentrasi tersebut, perubahan jumlah bakteri dari sediaan cair menjadi serbuk sangat jauh menurun menjadi 4,45 log CFU/ $\mathrm{mL}$. Kandungan maltodekstrin yang semakin tinggi akan menyebabkan jumlah bakteri yang ada di dalam sediaan akan semakin sedikit.Selain tingginya konsentrasi penyalut, penggunaan suhu yang tinggi juga akan menyebabkan penurunan jumlah bakteri pada serbuk probiotik. Proses perubahan probiotik cair menjadi serbuk dilakukan dengan menggunakan BUCHI mini spray dryer dengan penerapan suhu inlet $131-133^{\circ} \mathrm{C}$ dan suhu outlet $65-70{ }^{\circ} \mathrm{C}$. Oleh karena itu, bakteri probiotik tidak mampu bertahan dan mengalami penurunan viabilitas sel dalam proses mikroenkapsulasi. Suhu yang tinggi saat proses pengeringan menggunakan spray drying mempengaruhi viabilitas bakteri probiotik (Weinbreck, Bodnar \& Marco, 2010). Hal ini sesuai dengan hasil penelitian Fu dan Etzel (1995) bahwa kerusakan seluler selama proses spray drying dapat diakibatkan oleh pemanas dalam atomizer, dehidrasi sel dan

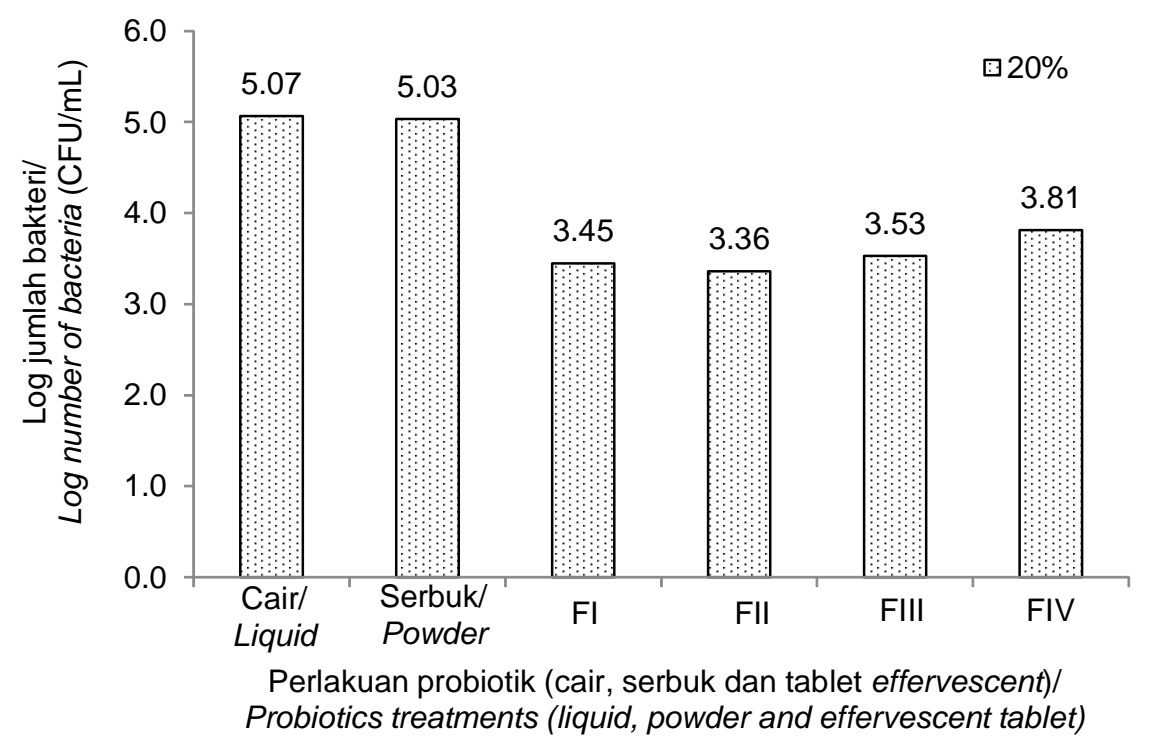

Gambar 2. Jumlah bakteri probiotik dalam bentuk cair, serbuk dan tablet effervescent berpenyalut $20 \%$ maltodekstrin

Figure 2. The number of probiotic bacteria in the form of liquid, powder and effervescent tablet in $20 \%$ maltodextrin filler 


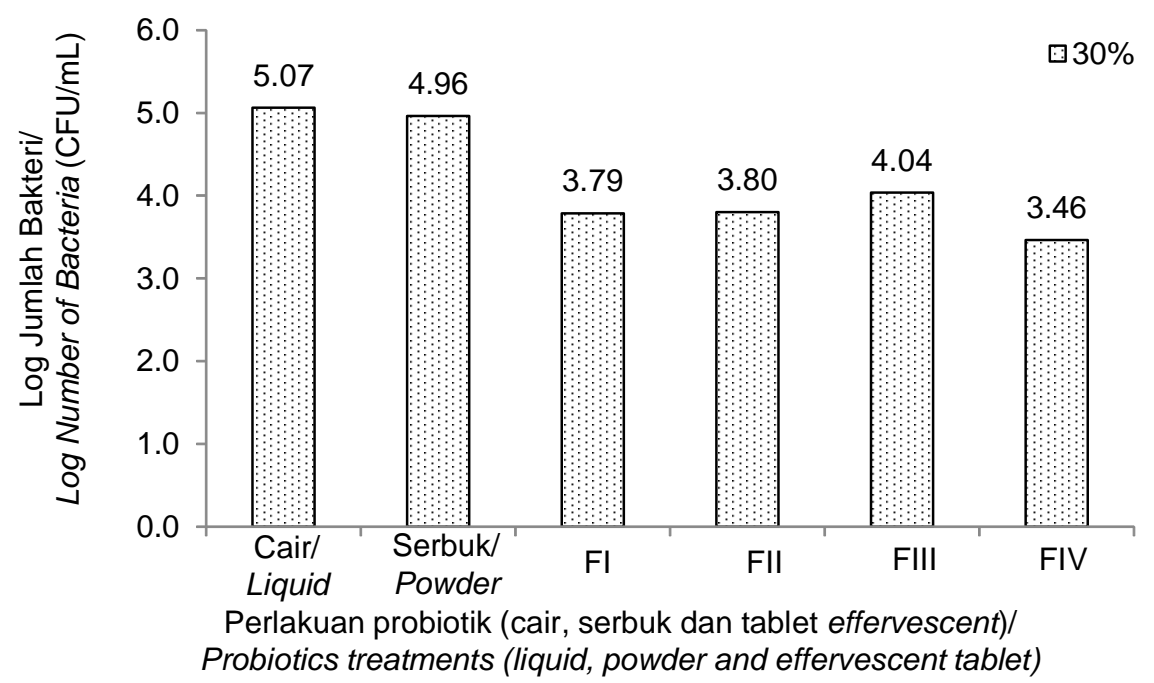

Gambar 3. Jumlah bakteri probiotik dalam bentuk cair, serbuk dan tablet effervescent berpenyalut $30 \%$ maltodekstrin

Figure 3. The number of probiotic bacteria in the form of liquid, powder and effervescent tablet in $30 \%$ maltodextrin filler

inaktivasi panas. Serupa dengan hasil penelitian Teixeria, Castro, dan Kirby (1995b) bahwa viabilitas akan menurun selama spray drying karena adanya kerusakan komponen sel, membran sel, dinding sel dan DNA.

Jumlah bakteri pada tablet mengalami penurunan pada masing-masing formula pada ketiga konsentrasi penyalut $(20 \%, 30 \%$ dan $40 \%)$. Penurunan ini disebabkan penambahan bahan lain yaitu asam sitrat, natrium bikarbonat, magnesium stearat dan laktosa sehingga hasil TPC lebih rendah dibanding dengan probiotik cair dan serbuk probiotik.

Anwar et al. (2010) menjelaskan bahwa semakin banyak kandungan maltodekstrin dalam formula sediaan tablet maka pengikatan terhadap partikel komponen lain semakin kuat sehingga sediaan akan semakin kuat. Hal ini diasumsikan bahwa probiotik terlindungi dari proses oksidasi dan terhindar dari kerusakan pada waktu penyimpanan sehingga umur simpan probiotik tersebut meningkat. Menurut Faradiba et al. (2013), bahan lain yang mempengaruhi oksidasi tablet effervescent adalah asam sitrat yang bersifat higroskopis, sehingga diperlukan penyimpanan yang baik setelah terbentuk sediaan effervescent.

Menurut Nagashima et al. (2013), jumlah bakteri probiotik lebih rendah dalam bentuk tablet effervescent daripada dalam bentuk serbuk setelah dua bulan penyimpanan pada $25^{\circ} \mathrm{C}$ dalam pengemasan plastik tertutup. Hal ini disebabkan adanya tekanan yang kuat saat pembuatan tablet sehingga mengakibatkan terganggunya viabilitas mikroba. Hal ini sesuai pula dengan hasil penelitian Texeira et al. (1995b) dalam
Harmayani, Ngatirah, Rahayu, dan Utami (2001) yang melaporkan penurunan viabilitas sel bakteri Lactobacillus delbrueckii subsp. bulgaricus dengan adanya suhu inlet $200^{\circ} \mathrm{C}$ dan outlet $70^{\circ} \mathrm{C}$, selama penyimpanan pada beberapa variasi suhu.

\section{Uji viabilitas bakteri probiotik}

Berdasarkan hasil viabilitas tablet effeervescent dengan penyalut $20 \%$ maltodekstrin (P1) pada air tambak dapat dilihat bahwa hasil TPC tertinggi terdapat pada formula I (Q1) yaitu 5,67 log CFU/mL sedangkan yang terendah pada formula II (Q2) yaitu 4,76 log CFU/mL (Gambar 5). Satu-satunya bahan yang memiliki efek signifikan secara statistik adalah natrium bikarbonat. Peningkatan konsentrasi bahanbahan pada komposisi tablet (Tabel 1) atau dalam jumlah serbuk probiotik akan mendukung stabilitas bakteri ini dalam produk tablet effervescent.

Hasil pengujian viabilitas sel bakteri pada tablet effervescent dengan konsentrasi 30\% maltodekstrin (P2) pada air tambak menunjukkan bahwa nilai TPC tertinggi terdapat pada formula IV (Q4) yaitu 6,46 log $\mathrm{CFU} / \mathrm{mL}$ sedangkan yang terendah pada formula III yaitu 5,60 log CFU/mL (Gambar 5). Gambar ini menunjukkan bahwa efek dari komposisi natrium bikarbonat pada tablet berpengaruh positif dalam melindungi jumlah bakteri probiotik tablet effervescent.

Pengujian viabilitas sel pada tablet effervescent dengan penyalut maltodekstrin konsentrasi $40 \%$ menunjukkan bahwa hasil TPC tertinggi terdapat pada formula IV (Q4) yaitu 6,21 log CFU/mL sedangkan 


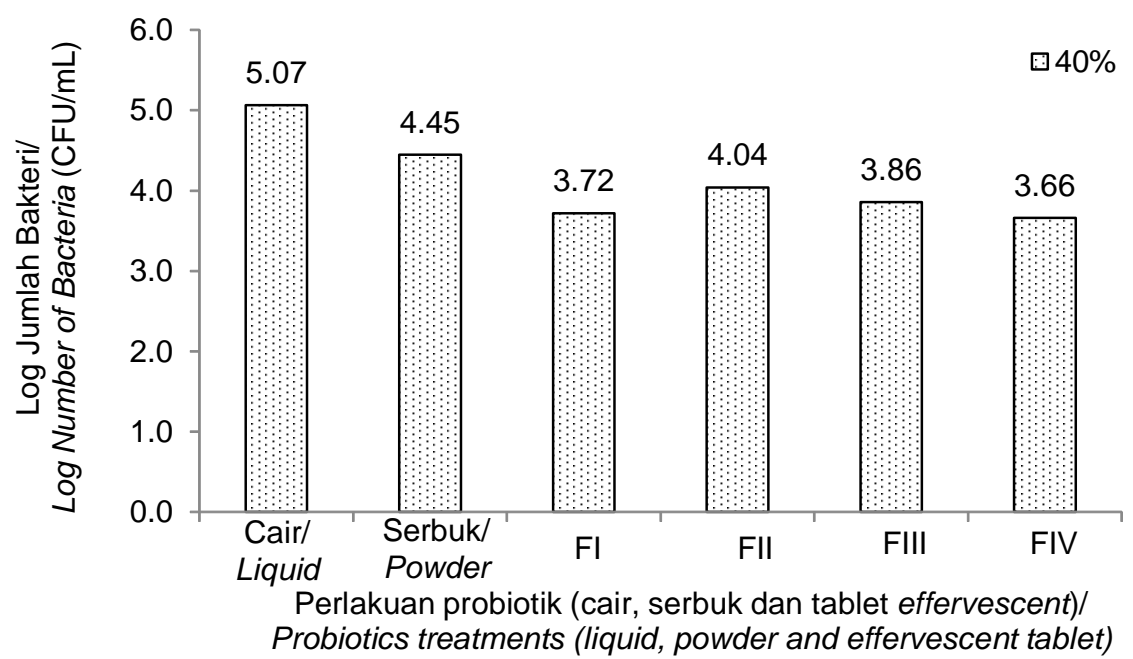

Gambar 4. Jumlah bakteri probiotik dalam bentuk cair, serbuk dan tablet effervescent berpenyalut $40 \%$ maltodekstrin

Figure 4. The number of probiotic bacteria in the form of liquid, powder and effervescent tablet in $40 \%$ maltodextrin filler

yang terendah pada formula III (Q3) yaitu 4,66 log CFU/ $\mathrm{mL}$. Jika dibandingkan dengan histogram viabilitas bakteri pada tablet dengan konsentrasi $30 \%$ maka jumlah bakteri pada konsentrasi $40 \%$ terutama pada formula IV lebih rendah meskipun perbandingan asam sitrat dan natrium bikarbonat sama. Hal ini disebabkan karena semakin tinggi konsentrasi penyalut maka kemampuan melindungi probiotik yang ada di dalam tablet akan semakin berkurang. Hal ini serupa dengan hasil penelitian Warni (2012) yang menunjukkan bahwa semakin tinggi konsentrasi penyalut maka kemampuan untuk melindungi bakteri semakin berkurang. Sementara itu, penelitian Meng, Stanton, Fitzgerald, Daly, dan Ross (2008) menunjukkan bahwa nilai viabilitas sel menurun setelah pengeringan dan penyimpanan. Penurunan viabilitas sel secara drastis

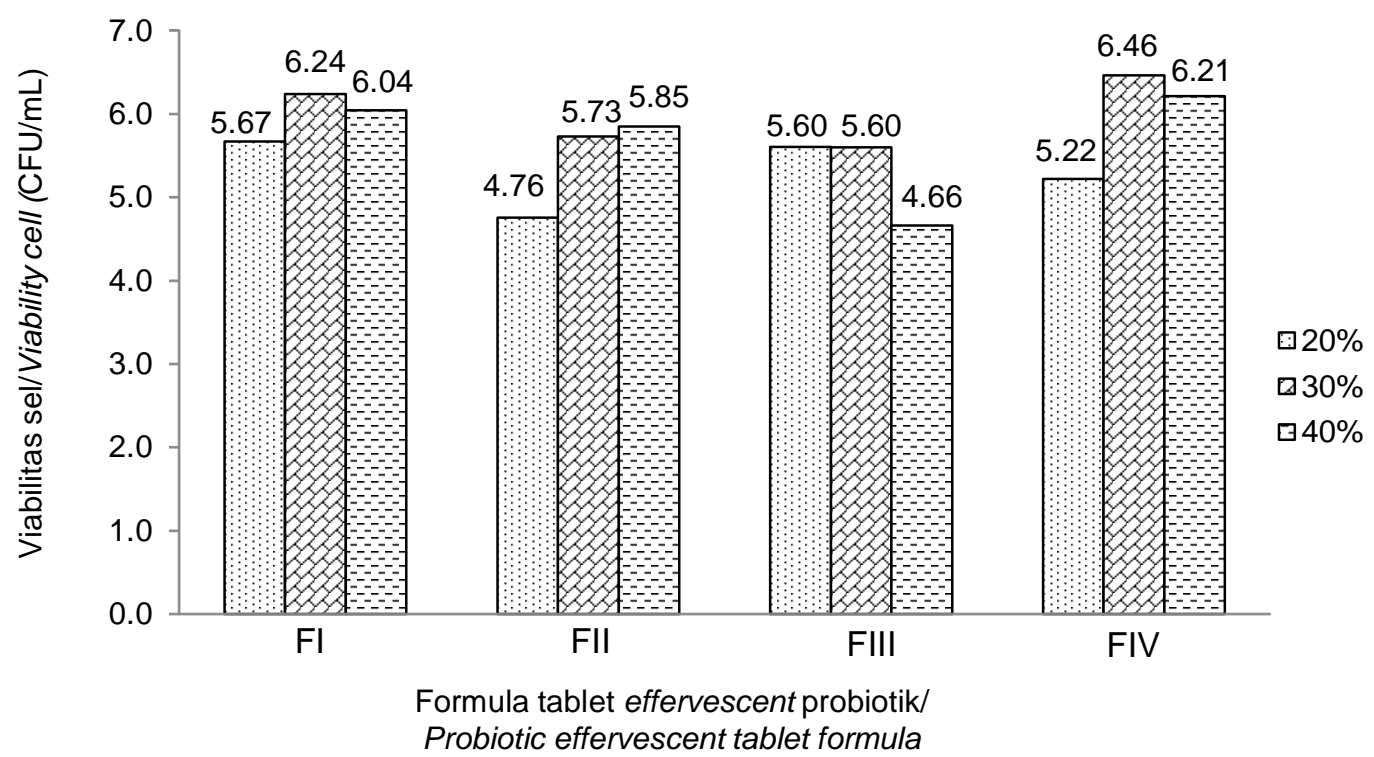

Gambar 5. Viabilitas sel tablet effervescent probiotik pada berbagai formula dan penyalut maltodekstrin (20, 30 dan $40 \%)$

Figure 5. Cell viability of effervescent probiotics tablet on various formula and maltodekstrin fillers (20, 30 and $40 \%)$ 
terjadi setelah pengeringan menggunakan spray dryer dan setelah penyimpanan selama dua minggu. Penurunan yang terjadi setelah pengeringan dari 3,25 x $10^{7} \mathrm{CFU} / \mathrm{mL}$ menjadi $2,15 \times 10^{7}$, setelah penyimpanan selama dua minggu total penurunannya menjadi $4 \times 10^{2} \mathrm{CFU} / \mathrm{mL}$. Hal ini merupakan masalah utama pada produksi probiotik secara komersial.

Faktor konsentrasi penyalut $(P)$ dan formula tablet effervescent $(Q)$ berpengaruh nyata $(p<0,05)$ terhadap viabilitas bakteri probiotik pada sampel air tambak udang, sedangkan interaksi keduanya (PQ) tidak memberikan pengaruh nyata yang signifikan. Pada penelitian ini, jumlah sel bakteri probiotik terendah dihasilkan dari perlakuan konsentrasi $40 \%$ pada Formula III (p3q3) dengan nilai 4,66 log CFU/mL, sedangkan jumlah sel tertinggi didapatkan dari perlakuan konsentrasi 30\% pada formula IV (p2q4) sebesar 6,46 log CFU/mL. Semakin tinggi jumlah bakteri probiotik yang terlihat dari nilai TPC, semakin besar kemungkinan menghambat bakteri patogen, sehingga konsentrasi penyalut yang paling baik untuk penelitian ini adalah 30\% maltodekstrin pada formula IV. Pada komposisi formula tersebut, maltodektrin mampu melindungi bakteri probiotik dengan jumlah yang lebih stabil.

\section{Uji waktu larut}

Hasil uji waktu larut menunjukkan bahwa tablet effervescent $20 \%$ maltodekstrin (P2) paling cepat larut pada formula III (Q3) yaitu 21 menit dan waktu larut paling lambat adalah formula II (Gambar 6.). Perbedaan waktu larut yang sangat lama antara formula II dengan formula III disebabkan oleh komposisi natrium bikarbonat yang berbeda. Semakin banyak kandungan natrium bikarbonat maka waktu larut tablet akan semakin cepat. Hal ini sesuai dengan penelitian Ansar (2011) yang menyatakan bahwa semakin banyak natrium bikarbonat yang ditambahkan maka tablet akan cenderung lebih cepat larut di dalam air. Hal ini disebabkan oleh natrium bikarbonat yang merupakan sumber utama karbondioksida dalam tablet effervescent. Karbondioksida yang terdapat di dalam tablet effervescent akan memecah tablet ketika dimasukkan ke dalam air karena karbondioksida tidak dapat larut dalam air, sehingga ketika tablet effervescent dimasukkan ke dalam air, karbondioksida akan keluar bersamaan dengan larutnya tablet yang ditandai dengan adanya gelembung-gelembung udara kecil yang keluar dari tablet effervescent.

Uji waktu larut tablet effervescent $30 \%$ dan $40 \%$ maltodekstrin menunjukkan bahwa tablet yang paling cepat larut terdapat pada formula IV (Q4) yaitu 20 menit dan 21 menit, sedangkan waktu larut terlama pada formula II (Q2) yaitu 93 menit dan 103 menit. Diduga tekstur tablet formula II lebih keras daripada formula IV. Hal ini sesuai dengan hasil penelitian Ansar et al. (2009) di mana tablet yang padat akan tenggelam terlebih dahulu kemudian naik ke permukaan, sehingga waktu yang dibutuhkan untuk larut sempurna semakin lama. Tablet yang rapuh akan langsung larut dan pecah di permukaan air, sehingga waktu larutnya relatif lebih cepat. Semakin lama waktu yang diberikan pada

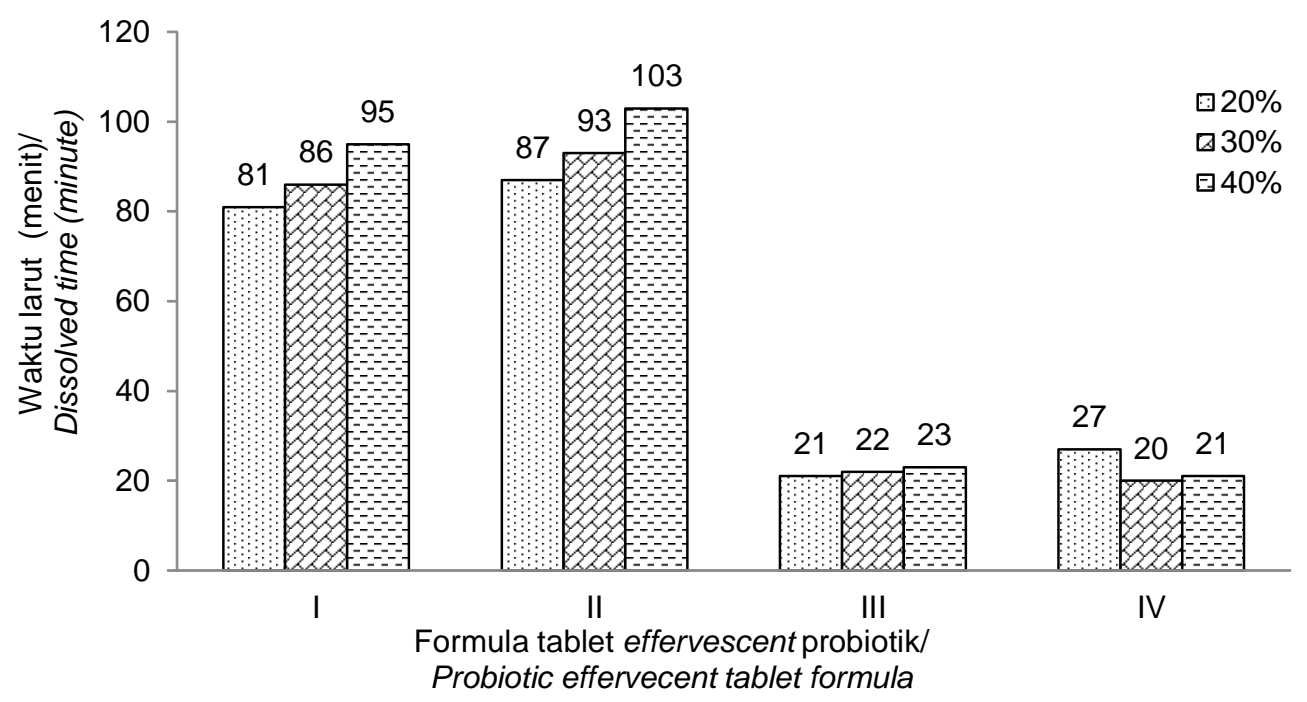

Gambar 6. Waktu larut tablet effervescent probiotik pada berbagai formula dan penyalut maltodekstrin (20, 30 dan $40 \%)$

Figure 6. Dissolved time of effervescent probiotics tablet on various formula and maltodextrin fillers (20, 30 and $40 \%$ ) 
proses pentabletan, maka akan semakin lama pula tablet tersebut larut dalam air. Pengaruh ini disebabkan oleh waktu yang diberikan terhadap total gaya tertentu dalam proses pentabletan yang akan menekan partikel-partikel penyusun tablet semakin lama dan akhirnya semakin memadat, sehingga rongga yang berada di dalam tablet akan semakin mengecil. Rongga yang semakin mengecil akan semakin mempersulit air yang berperan sebagai zat pelarut untuk masuk ke dalam rongga-rongga tersebut, sehingga tablet akan semakin lama larut dalam air.

\section{Pengukuran pH}

Nilai $\mathrm{pH}$ larutan tablet effervescent probiotik pada konsentrasi $20 \%$ formula I (Q1) adalah 5; yang merupakan nilai $\mathrm{pH}$ terendah dibandingkan dengan konsentrasi $30 \%$ dan $40 \%$ (Gambar 7). Hasil pengukuran dikatakan baik apabila mendekati netral. Hal ini sesuai dengan hasil penelitian Lestari dan Trisusilawati (2010) di mana penambahan asam fumarat menyebabkan penurunan $\mathrm{pH}$ baik pada penggunaan natrium bikarbonat level tinggi maupun rendah. Sebaliknya penambahan natrium bikarbonat akan meningkatkan $\mathrm{pH}$ baik itu pada penggunaan asam fumarat level tinggi maupun asam fumarat level rendah.

Secara umum, nilai $\mathrm{pH}$ tablet dengan konsentrasi penyalut $20 \%, 30 \%$ dan $40 \%$ maltodekstrin adalah mendekati netral. Pada penelitian ini tercatat bahwa nilai $\mathrm{pH}$ tablet effervescent yang terukur antara 5-7.
Hal ini menunjukkan bahwa kisaran derajat keasaman $(\mathrm{pH})$ tablet selama penelitian masih berada dalam batas yang cukup baik bagi udang. Menurut Kumalaningsih Wigyanto, Vitta dan Triyono (2014) bakteri probiotik dengan jumlah besar terdapat pada $\mathrm{pH} 5$ dan memberikan hasil paling baik dalam mempertahankan viabilitas bakteri. Pada pH ini bakteri sudah memasuki fase log. Sebaliknya menurut Khan dan Wiyana (2011), nilai pH rendah (pH2,5-3) memiliki sifat merusak yang sangat kuat terhadap bakteri probiotik yang terenkapsulasi.

\section{KESIMPULAN}

Dari hasil penelitian dapat disimpulkan bahwa viabilitas (jumlah bakteri) probiotik pada tablet effervescent dengan penyalut maltodekstrin yang paling baik dan paling efektif dalam menjaga kestabilan bakteri adalah formula IV dengan konsentrasi $30 \%$. Tablet dengan formula tersebut dapat mempertahankan jumlah bakteri pada 6,46 log CFU/ $\mathrm{mL}$ dan dapat larut dalam waktu 20 menit. Nilai pH dari 12 perlakuan tersebut adalah 5-7.

\section{DAFTAR PUSTAKA}

Aneja, K. R. (2003). Experiment in microbiology, plant pathology and biotechnology. India. New Age International Publisher. 4th Ed. pp. 606

Anekella, K. (2011). Microencapsulation of probiotics (Lactobacillus acidophilus and Lactobacillus rhamnosus) in raspberry powder by spray drying:
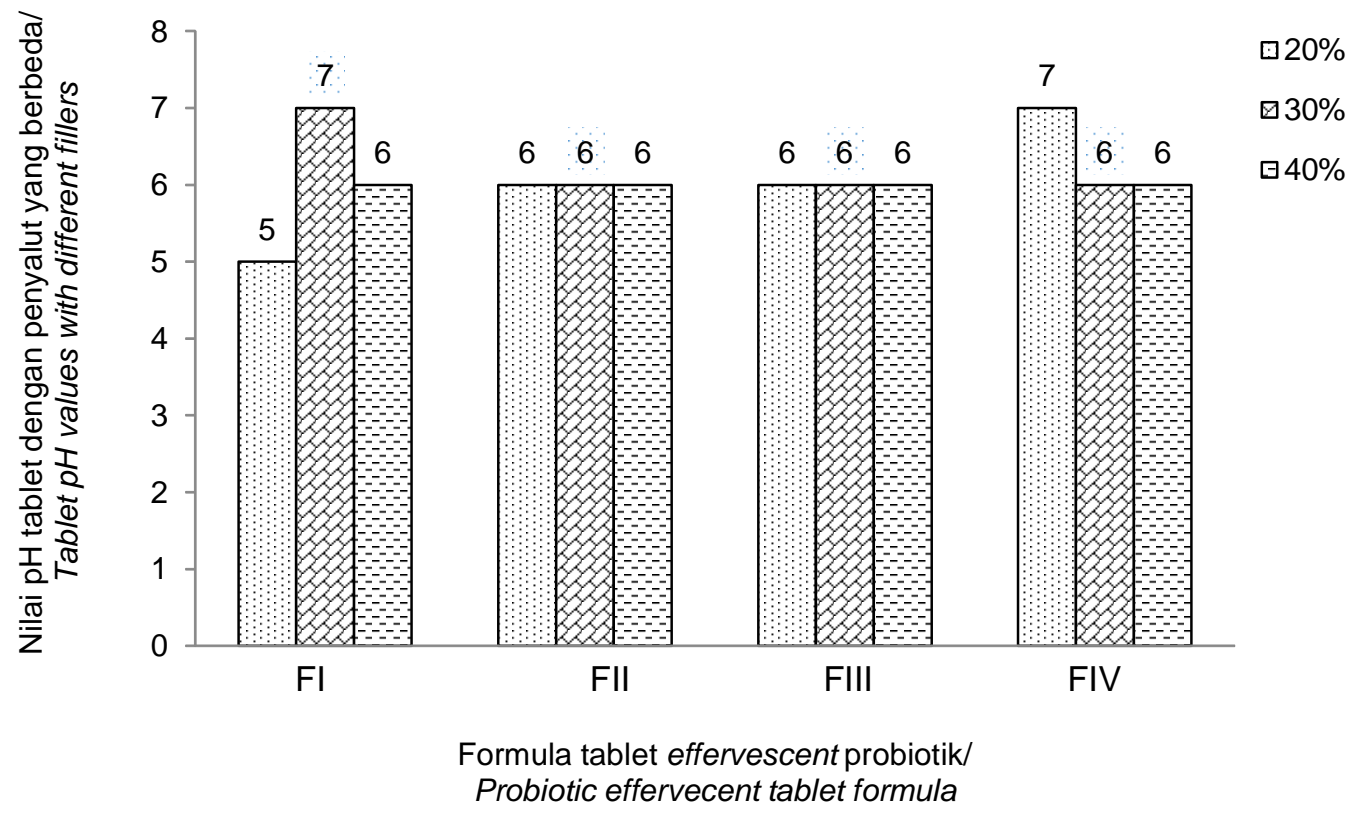

Gambar 7. Nilai pH tablet effervescent pada konsentrasi formula dan penyalut yang berbeda Figure 7. $\mathrm{pH}$ values of effervescent tablets in various formula and filler concentration 
optimization and storage stability studies. Thesis. Department of Bioresource Engineering, Faculty of Agricultural and Environmental Sciences, McGill University. 128.

Ansar, Rahardjo, B., Noor, Z., \& Suyitno. (2006). Optimasi formula dan gaya tekan terhadap sifat tablet effervescent buah markisa. Jurnal Teknol. dan Industri Pangan, XVII(1), 23-27.

Ansar, B., Rahardjo, Z., Noor., \& Rochmadi. (2009). Optimasi teknik pembuatan tablet effervescent sari buah dengan response surface method (RSM). J. Teknol. dan Industri Pangan, 20(1), 25-31.

Ansar. (2011). Optimasi formula dan gaya tekan terhadap tekstur dan kelarutan tablet effervescent buah markisa. Jurnal Teknologi Pertanian, 12(2), 109-114.

Anwar, E., Joshita, D., \& Bahtiar, A. (2010), Pemanfaatan maltodekstrin pati terigu sebagai eksipien dalam formulasi sediaan tablet dan niosom. Majalah IImu Kefarmasian, 1(1), 34-46.

Atmomarsono, M., Muliani, \& Tampangallo, B. R. (2010). Aplikasi bakteri probiotik untuk peningkatan sintasan dan produksi udang windu di tambak. Prosiding Forum Inovasi Teknologi Akuakultur, 269-278

Chanratchakool, P., \& Limsuwan, C. (1998). Application of PCR and formalin treatment to prevent white spot disease in shrimp. In Flegel TW (ed) Advances in Shrimp Biotechnology. National Center for Genetic Engineering and Biotechnology, Bangkok.

Chavarri, M., Maranon, I., \& Villaran, M. C. (2015). Encapsulation technology to protect probiotics bacteria. Chapter 23 Probiotics. 502-540.

Direktoral Jenderal Pengawasan Obat dan Makanan. (1979). Farmakope Indonesia. Edisi III. Departemen Kesehatan Republik Indonesia. Jakarta. 6-7.

Faradiba, Hasyim, N., \& Zahriati. (2013). Formulasi granul effervescent ekstrak etanol daun jambu biji (Psidium guajava LINN). Majalah Farmasi dan Farmakologi, 17(2), 47-50.

Farzanfar, A. (2006) The use of probiotics in shrimp aquaculture. FEMS Immunoligy Medical Microbiology, 48, 149-158.

Flegel, T. W. (2012). Historic emergence, impact and current status of shrimp pathogens in Asia. Journal of Invertebrate Pathology, 110, 166-173.

Fu, W. Y., \& Etzel, M. R. (1995). Spray drying of Lactococcus lactis ssp. lactis C25 on celluler injury. Journal Food Science, 60(1), 195-200.

Harmayani, E., Ngatirah, Rahayu, E. S., \& Utami, T. (2001). ketahanan dan viabilitas probiotik bakteri asam laktat selama proses pembuatan kultur kering dengan metode freeze dan spray drying. Jurnal Teknol. dan Industri Pangan, XII (2), 126-132

Johnson, J. A. C., \& Etzel, M. R. (1995). Properties of Lactobacillus helveticus CNRZ-32 attenuated by spray-drying, freeze drying of freezing. J. Dairy Sci., 78, 761-768.

Kailaku, S. I., Sumangat, J., \& Hernani. (2012). Formulasi granul effervescent kaya antioksidan dari ekstrak daun gambir. J. Pascapanen, 9(1), 27-34.
Kailasapathy, K. (2002). Microencapsulation of probiotic bacteria: technology and potential applications. Curr. Issues Intest. Microbiol., 3, 39-48.

Kanjana, K., Tawut, R., Asuvapongpatana, S., Withyachumnarnkul, B., \& Wongprasert, K. (2011). Solvent extracts of the red seaweed Gracilaria fisheri prevent Vibrio harveyi infections in the black tiger shrimp Penaeus monodon. Fish \& Shellfish Immunology, 30, 389-396.

Karunasagar, I., Pai, R., Malathi, G. R. \& Karunasagar, I. (1994). Mass mortality of Penaeus monodon larvae due to antibiotic-resistant Vibrio harveyi infection. Aquaculture, 128, 203-209.

Kellar, S., Poshini, F., He, L., Penzotti, S., Bedu-Addo, F., \& Payne, K. (2005). Preformulation development studies to evaluate the properties of epigallocatechin gallate (EGCG), Cardinal Health Pharmaceutical Development ; NJ08873.

Khan, M. S. \& Wiyana, A. (2011), Karakteristik ketahanan bakteri asam laktat indigeneous kefir sebagai kandidat bakteri probiotik pada kondisi saluran pencernaan in vitro, Institut Pertanian Bogor. Bogor.

Kumalaningsih, S., Wigyanto., Vitta R. P. \& Triyono, A. (2014). Pengaruh jenis mikroorganisme dan $\mathrm{pH}$ terhadap kualitas minuman probiotik dari ampas tahu. Thesis, Universitas Brawijaya, Malang.

Lestari. A. B. S. \& Trisusilawati. M. Y. (2010). Pengaruh asam fumarat-natrium bikarbonat terhadap kualitas granul effervescent the hijau secara granulasi kering. Majalah Farmasi Indonesia, 21(4), 231-237.

Meng, X. C., Stanton, C., Fitzgerald, G. F., Daly, C., \& Ross, R. P. (2008). Anhydrobiotics: the challenges of drying probiotic cultures. Food Chemistry, 106, 1406-1416.

Mohrle, R., Attwood, D., \& Banker, C. S. (1989). Effect of compression force, humidity, and disintegrate concentration on the disintregration and dissolution of directly compressed furosemide tablets using croscarmellose sodium as disintegrate. Tropical Journal of Pharmaceutical Research, 2(1), 285-286.

Muliani., Nurbaya., \& Atmomarsono, M. (2010). Penggunaan probiotik pada pemeliharaan udang windu (Panaeus monodon) dengan dosis pakan yang berbeda. Prosiding Forum Inovasi Teknologi Akuakultur. 249-259.

Nagashima, A. I., Pansiera, P. E., Baracat, M. M., \& Gomez, R. J. H. C. (2013). Development of effervescent products in powder and tablet form suplemented with probiotics Lactobacillus acidophilus and Saccaromyces boulardii. Food Sci Technol., 33(4), 605-611.

Najib. (2015). Komunikasi pribadi.

Nisha, Y. R., Milind, B. J., \& Imran, A. K. (2013). Probiotic delivery systems: applications, challenges and prospective. Internat. Res. J. of Pharmacy, 4(4), 1-9.

Osmond, L. M., Purwijantiningsih, \& Pranata, F. S. (2015). Viabilitas bakteri dan kualitas permen probiotik dengan variasi jenis enkapsulan. Skripsi, Universitas Atma Jaya Yogyakarta, Yogyakarta.

Poernomo, A. (2004). Teknologi probiotik untuk mengatasi permasalahan tambak udang dan 
Pengaruh Konsentrasi Penyalut terhadap Viabilitas Bakteri dan Daya Larut Tablet.........(Devi Ambarwaty O., et al.)

lingkungan budidaya. Makalah disampaikan pada Simposium Nasional Perkembangan IImu dan Inovasi Teknologi dalam Bidang Akuakultur. Semarang, 27-29 Januari 2004, 24.

Susantho, A. (2012) Mikroenkapsulasi. http:// anthosusantho.wordpress.com mikroenkapsulasi-2/ . Diakses pada tanggal 31 Maret 2016 pukul 21.00 WIB.

Tampangallo, B. R., Pakidi, C. S. \& Rantetondok, A. (2013). Sintasan benih udang windu yang dipelihara dengan beberapa jenis probiotik RICA dan resistensinya terhadap bakteri patogen $V$. harveyi. Prosiding Forum Inovasi Teknologi Akuakultur. 863874.

Teixeira, P., Castro, H., \& Kirby, R. (1995a). Spray drying as a method for preparing concentrated cultures of Lactobacillus bulgaricus. 7. www.repositorio.ucp.pt.

Teixeira, P., Castro, M. H., Malcata, F. X., \& Kirby, R. M. (1995b). Survival of Lactobacillus delbrueckii ssp.
Bulgaricus following spray drying. Journal Dairy Science, 78,105-1031.

Triana, E., Yulianto, E., \& Nurhidayat, N. (2006). Uji viabilitas Lactobacillus sp. Mar 8 terenkapsulasi. Biodiversitas, 7(2), 114-117.

Verschuere, L., Rombaut, G., Sorgeloos, P., \& Verstraete, L. (2000). Probiotic bacteria as biological control agents in aquaculture. Microbiology and Molecular Biology Reviews, 64(4), 655-671.

Warni, D. (2012). Pengaruh komposisi bahan penyalut dan kondisi spray drying terhadap karakteristik mikrokapsul oleoresin jahe. Skripsi, Institus Pertanian Bogor, Bogor.

Weinbreck, F. I., Bodnar, M. \& Marco, L. (2010). Can encapsulation lengthen the shelf- life of probiotic bacteria in dry products. International Journal of Food Microbiology, 136, 364-367. 
JPB Kelautan dan Perikanan Vol. 13 No. 2 Tahun 2018: 153-163 